\title{
RETORIKA POLITIK SUSILO BAMBANG YUDHOYONO: PENDEKATAN ANALISIS WACANA KRITIS
}

\author{
Fadel Mozefani ${ }^{1}$ Guntur F. Prisanto $^{2}$ Niken F. Ernungtyas $^{3}$ Irwansyah $^{4}$ \\ ${ }^{1}$ Sekolah Tinggi Ilmu Komunikasi Inter Studi \\ ${ }^{2}$ Sekolah Tinggi Ilmu Komunikasi Inter Studi \\ ${ }^{3}$ Sekolah Tinggi Ilmu Komunikasi Inter Studi \\ ${ }^{4}$ Universitas Indonesia \\ Email:fadelcao@gmail.com
}

\begin{abstract}
ABSTRAK
Penelitian ini bertujuan untuk menganalisis retorika pemikiran dan gagasan Susilo Bambang Yudhoyono (SBY) sebagai Presiden Republik Indonesia keenam. Melalui pidatonya (24 Juli 1818), di YouTube, dan kemudian ditulis di media online CNN, terkait dengan proses pembentukan koalisi partai politik yang membawa Prabowo Subianto sebagai kandidat presiden dalam pemilihan 2019. Teori yang digunakan dalam penelitian ini adalah kualitatifdeskriptif dengan pendekatan analitis wacana kritis dari Teun A. Van Dijk dilihat dalam dimensi; (1) struktur teks, (2) kognisi sosial, dan (3) konteks sosial, kemudian dikaitkan dengan teori komunikasi massa dari HarollD Laswell. Hasil penelitian ini dirangkum dengan model komunikasi massa dalam bentuk, fungsi dan makna. Hasil yang diperoleh dari penelitian ini membuat model komunikasi massa dengan struktur teks (bentuk), kognisi sosial (fungsi) dan konteks sosial (makna).
\end{abstract}

Kata Kunci: Retorika, Analisis Wacana Kritis, Pidato

\section{POLITICAL RETORICS OF SUSILO BAMBANG YUDHOYONO: APPROACH CRITICAL DISCOURSE ANALYSIS}

\begin{abstract}
This study aims to analyze the rhetoric of the thoughts and ideas of Susilo Bambang Yudhoyono (SBY) as the sixth President of the Republic of Indonesia. Through his speech (July 24 '18), on YouTube, and later written on CNN online media, related to the process of forming a political party coalition that brought Prabowo Subianto as a presidential candidate in the 2019 election. The theory used in this study was qualitative-descriptive with an analytical approach critical discourse from Teun A. Van Dijk seen in dimensions; (1) text structure, (2) social cognition, and (3) social context, then associated with mass communication theory from HarollD Laswell. The results of this study are summarized with the mass communication model in form, function and meaning. The results obtained from this study create a model of mass communication with text structure (form), social cognition (function) and social context (meaning).
\end{abstract}

Keywords: Rhetoric, Critical Discourse Analysis, Speech 
Korespondensi: Nurma Tri Amalia. Universitas Ahmad Dahlan. Jalan Ringroad Selatan, Tamanan, Banguntapan, Yogyakarta. No. HP, WhatsApp: $\mathbf{0 8 5 2 6 3 0 1 0 1 4 5 ~ E m a i l : ~ i n d a h . w e n e r d a @ ~ c o m m . u a d . a c . i d ~}$

\section{PENDAHULUAN}

Setiap lima tahun sekali Indonesia merayakan euforia pesta demokrasi, yakni pemilihan Presiden dan wakil Presiden. Tahun 2018 sebagai awal kampanye berbagai partai mempersiapkan calonnya untuk diusung sebagai calon presiden dan wakil presiden sesuai dengan kriteria dan penilaian mereka. Oleh karenanya di tahun 2018 itu, Indonesia disibukkan dengan kampanye dan pemilihan, dimana para kader dan relawan serta tim sukses mulai mempersiapkan diri merancang strategi kampanye politik untuk pemilihan umum presiden (pilpres) dan pemilihan legislatif (pileg) pada April 2019. Para politisi membuat berbagai strategi politik untuk memperoleh simpati dari seluruh lapisan masyarakat. Pencitraan dilakukan dan dianggap lumrah demi memperoleh simpati masyarakat. Kuatnya persaingan antara partai politik telah membuat sejumlah partai besar saling memanas, saling menjatuhkan satu sama lain dan berebut memposisikan diri menjadi yang terbaik.

Banyaknya partai-partai yang turut berperan serta dalam Pemilu atau dikenal dengan sistem multipartai, menimbulkan suatu konsekuensi yaitu tidak adanya partai yang mampu mendapatkan mayoritas mutlak suara dalam parlemen. Kondisi itu memaksa partai-partai politik untuk saling berkoalisi dalam membentuk pemerintahan. Implikasinya setiap partai politik yang ingin maju ke tahap Pilpres harus mengadakan koalisi dengan partai lain sehingga dapat mendorong jumlah suara untuk mengusung calon yang dipilih oleh partai koalisi. Tanpa adanya dukungan dari berbagai partai yang berkoalisi sulit rasanya mempersiapkan kemenangan capres dan cawapres yang diusung. Diperlukan visi dan misi bersama dalam sebuah partai untuk dapat berkoalisi mengusung pilihannya itu.

Pada pesta demokrasi untuk capres dan cawapres yang akan menjabat pada 2019 - 2024 ini, hanya ada dua calon yang ditampilkan / dimunculkan ke publik, yang dikenal dengan sebutan sebagai kubu 1, 'Poros Jokowi' lalu kemudian menjadi sebagai (01) dan kubu 2, 'Poros Prabowo', yang disebut sebagai (02). Pada Poros Jokowi yakni (01) telah membangun koalisi dengan merangkul sejumlah partai politik (Parpol), diantaranya yaitu Partai Demokrasi Indonesia Perjuangan (PDIP), Partai Golongan Karya (Golkar), Partai Kebangkitan Bangsa (PKB), Partai Hati Nurani Rakyat (Hanura), Partai Nasional Demokrat (NasDem), Partai Persatuan Indonesia (Perindo), Partai Persatuan Pembangunan (PPP) dan Partai Solidaritas Indonesia (PSI). Sementara, Poros Prabowo (02) di isi hanya 3 partai saja yakni Partai Gerakan Indonesia Raya (Gerindra), Partai Demokrat, Partai Amanat Nasional (PAN) dan Partai Keadilan Sejahtera (PKS). Dalam hal koalisi ini, Susilo Bambang Yudhoyono (SBY) merupakan salah satu tokoh politik di Indonesia yang seringkali menyampaikan pidato politik. Khususnya, pada pertemuan-pertemuan yang dilakukan dalam proses menjalin kesepakatan koalisi dengan para elit partai politik yang 
mengusung Prabowo Subianto sebagai capres 2019. Dalam pidato pertemuan politik pertamanya dengan Prabowo di tahun 2018 pada saat Ketua Umum Partai Gerindra tersebut berkunjung ke kediaman SBY tanggal 24 Juli di Mega Kuningan, Jakarta, SBY membabarkan beberapa hal penting yang menjadi pokok pembahasan dalam pertemuan tersebut. SBY menjelaskan terdapat kesamaan dan kesepakatan pandangan antara Partai Demokrat dan Partai Gerindra dalam berbagai permasalahan pokok yang sedang dihadapi di Indonesia. Kesamaan pandangan tersebut dijadikan komitmen dalam terbukanya peluang Partai Demokrat memasuki pintu koalisi Partai Gerindra untuk mengusung Prabowo Subianto sebagai calon presiden pada pilpres 2019. Pidato SBY merupakan suatu retorika dalam komunikasi politik yang dilakukan olehnya sebagai pemimpin partai politik di Indonesia.

Bagi Aristoteles, pidato merupakan seni untuk membujuk, mempengaruhi dan meyakinkan khalayak. Dalam pidato itu sendiri bisa diartikan sebagai keindahan berbahasa yang bersifat membenarkan (corective) memerintah (instructive) mendorong (suggestive) dan mempertahankan (defensive) (Surachman, 2006 : 190). Retorika sebagai seni berbicara tidak hanya diartikan sebagai suatu kemampuan berbicara secara lancar dan jelas, tapi retorika adalah kemampuan berbicara dan berpidato secara singkat, jelas, padat dan mengesankan. Retorika sebagai art of speech merupakan bentuk komunikasi yang diarahkan pada penyampaian pesan dengan maksud mempengaruhi khalayak agar dapat memperhatikan pesan yang disampaikan secara baik (Heryanto \& Zarkasy, 2012). Retorika sering disamakan dengan public speaking, yaitu suatu bentuk komunikasi lisan yang disampaikan kepada sekelompok orang banyak, tetapi sebenarnya retorika itu tidak hanya sekedar berbicara di hadapan umum, melainkan merupakan suatu gabungan antara seni berbicara dan pengetahuan suatu masalah tertentu untuk meyakinkan pihak orang yang banyak melalui pendekatan persuasif (Rakhmat, 1999).

Retorika politik melalui pidato yang dilakukan SBY merupakan suatu bentuk wacana yang disusun secara sistematis sehingga dipakailah analisis wacana kritis untuk menganalisis wacana retorika politik yang dilakukan SBY. Eriyanto (2001) mengungkapkan bahwa analisis wacana kritis menekankan pada konstelasi kekuatan yang terjadi pada proses produksi dan reproduksi makna. Hal ini diartikan bahwa individu tidak dianggap sebagai subjek yang netral yang dapat menafsirkan secara bebas sesuai dengan pikirannya karena sangat berhubungan dan dipengaruhi oleh kekuatan sosial yang ada dalam masyarakat. Oleh karenanya tujuan dari penelitian ini adalah untuk meganalisis retorika pikiran dan gagasan Susilo Bambang Yudoyono (SBY) dan untuk mengetahui apa saja isi pidato SBY yang terkandung dalam teks pidato sby untuk mengusung Parabowo sebagai Capers 2019 dengan menggunakan teori Analisis Wacana Kritis model Teun A. Van Dijk yang memiliki 3 dimensi di dalamnya : Analisis Teks, Kognisi Sosial, dan konteks Sosial dan dipadankan dengan teori komunikasi massa 
sehingga terbentuklah model bentuk, fungsi dan makna.

\section{METODE}

Untuk menganalisi wacana kritis dalam penelitian ini menggunakan metoda kualitatifdeskritif dengan pendekatan teori analisis wacana kritis dari Teun A Van Djik yang banyak dipakai. Van Dijk dalam hal ini banyak menformulasikan elemen-elemen wacana, sehingga bisa dipakai secara praktis. Model yang dipakai oleh van Dijk ini sering disebut sebagai "kognisi sosial" (Eriyanto 2001:221). Menurut Van Djik, penelitian terhadap wacana tidak cukup hanya sebatas dan didasarkan pada analisis teks semata, karena teks adalah hasil dari suatu praktik produksi yang harus juga diamati. Sedangkan proses produksi itu adalah suatu proses yang disebut sebagai kognisi sosial. Terbentuknya teks karena adanya suatu praktik diskursus dan praktik wacana. Di sini ada dua bagian, yaitu teks yang mikro yang merepresentasikan suatu topik permasalahan dalam berita, dan elemen besar berupa struktur sosial. Akan tetapi penelitian ini tidak akan meneliti secara detail bait-demi bait dalam kata dan kalimat namun lebih kepada hal yang mendasar sebagai kajian dalam komunikasi. Sehingga dalam hal ini penulis hanya memberikan batasan analisis yang berkaitan dengan komunikasi yaitu dalam kajian komunikasi dengan menggunakan teori Analisis Wacana Kritis model Teun A. Van Dijk yang meliputi di dalamnya adalah Analisis Teks, Kognisi Sosial, dan konteks Sosial.

Untuk model yang dipakai oleh Teun A Van Dijk ini sering disebut sebagai "kognisi sosial".
Menurutnya, penelitian atas wacana tidak cukup hanya dilihat pada analisis atas teks saja, dikarenakan teks hanya hasil dari suatu praktik produksi yang harus juga dilihat. Disini harus diamati juga bagaimana suatu teks diproduksi, sehingga kita memperoleh suatu kesimpulan dan pengetahuan mengapa teks bisa seperti itu. (Eriyanto, 2001 : 221). Teun A Van Dijk tidak hanya mengeksklusi modelnya saja dengan menganalisis teks semata. Akan tetapi dia juga melihat bagaimana struktur sosial, dominasi, dan kelompok kekuasaan yang ada dalam masyarakat dan bagaimana kognisi/pikiran dan kesadaran yang membentuk dan mempengaruhi terhadap teks tertentu (Eriyanto, 2001 : 224). Wacana oleh Van Dijk digambarkan mempunyai tiga dimensi/bangunan: teks, kognisi sosial, dan kontek sosial.

Jadi Inti dari analisis Teun Van Dijk adalah menggabungkan ketiga dimensi wacana tersebut ke dalam satu kesatuan analisis. Struktur teks dan strategi wacana yang digunakan untuk menegaskan suatu tema tertentu. Tataran dimensi kognisi sosial mempelajari proses produksi teks yang melibatkan kognisi individu dari pembuat teks itu. Adapun dengan dimensi analisis sosial adalah mempelajari bangunan wacana yang berkembang dalam masyarakat akan suatu masalah dan mengandung makna Karena ada paradigma kritis yaitu paradigma ilmu pengetahuan yang meletakkan epistemologi kritik Marxisme dalam seluruh metodologi penelitiannya. Sebuah fakta mengatakan paradigma kritis yang diinspirasikan dari teori kritis tidak bisa terlepas dari aliran Marxisme. Di 
satu pihak teori kritis merupakan salah satu aliran ilmu sosial yang berbasis pada ide-ide Karl Marx dan Engels (Denzin, 2000: 279-280). Metode dalam penelitian ini adalah kualitatif-deskritif dengan menggunakan dan teori analisis wacana kritis teori komunikasi massa yang difokuskan pada teks pidato SBY dan konteks yang terkait di dalamnya.

\section{HASIL DAN PEMBAHASAN}

Sesuai dengan perannya, media massa berfungsi sebagai pemberi informasi, pemberi identitas pribadi, sarana integrasi dan interaksi sosial, serta sebagai sarana hiburan. Seiring dengan perkembangannya, media cetak yang merupakan bagian dari media massa kini telah menjelma menjadi alat propaganda paling efektif. Melalui berita yang dikemasnya, media cetak berperan dalam mengubah pola pikir masyarakat. Masyarakat dengan mudah dipengaruhi oleh arah opini yang telah digiring media cetak untuk menjalin relasi antara wacana dan kekuasaan. Analisis wacana kritis diartikan bahwa tidak ada media massa yang sepenuhnya netral. Media bukanlah suatu aturan yang bebas, ia juga subyek yang mengkonstruksi realitas, lengkap dengan pandangan, bisa dan pemihaknya, karena ; 1 Media dimiliki oleh kelompok tertentu dan digunakan untuk mendominasi kelompok yang tidak dominan. Hal tersebut diatas dapat dipahami karena disetiap proses produksi, distribusi, dan konsumsi informasi terdapat kepentingan lain yang harus dipenuhi oleh media massa. Alasan tersebut menjadikan pembuatnya tidak bisa netral

Jadi media massa sesungguhnya berada di tengah realitas sosial yang sarad dengan berbagai kepentingan, konflik, dan fakta yang kompleks serta beragam. Analisis wacana kritis merupakan suatu kajian yang meneliti atau menganalisis bahasa yang digunakan secara alamiah, baik dalam bentuk tulisan maupun lisan. Penggunaan bahasa secara alamiah tersebut berarti penggunaan bahasa seperti dalam komunikasi sehari-hari. Dalam teori komunikasi, bahasa dianggap sebagai alat yang dapat menyampaikan sesuatu melalui percakapan, ucapan, dan tutur kata. Dalam hal ini adalah pidato SBY adalah bahasa tutur atau ucapan yang disampaikan ke publik berupa pidato. Adapun kata dalam analisis wacana adalah berupa teks, baik teks lisan maupun teks tulis. Teks disini mengacu pada bentuk transkripsi rangkaian kalimat (teks pidato SBY), sedangkan kalimat digunakan dalam ragam bahasa tulis dimana rangkaian kata membentuk kalimat dalam ragam bahasa lisan dan tulisan.

Pada dasarnya, analisis merupakan upaya yang dilakukan untuk menguak identitas objek analisis. Karena objek analisis wacana tidak pernah hadir sendirian, selalu disertai konteks, maka konteks merupakan penentu identitas objek analisis. Pada analisis wacana ini difokuskan objek kita pada salah satu media massa yang ada, yaitu teks pidato SBY. Melalui anlisis wacana tersebut, dapat diketahui motif/ideologi yang tersembunyi di balik teks berita tersebut secara sederhana, cara membaca yang lebih mendalam dan jauh ini disebut sebagai analisis wacana. Dan dalam pembahasan ini penulis mencoba untuk menganalisis struktur wacana yang terdapat dalam pidato SBY 


\section{RETORIKA}

Aristotels dalam bukunya, Retorika yang diterjemahkan oleh Dedeh SH (2018:38) Retorika adalah kombinasi dari ilmu logika dan cabang etika dari ilmu politik, sebagian mirip dengan dialektika, sebagian dengan pengenalan politik. Menurut Aristoteles, Retorika adalah the facult of seeing in any situation the available means of persuasion yang artinya kemampuan untuk melihat perangkat alat yang tersedia untuk mempersuasi. Sedangkan filsuf Plato mendefinisikan bahwa retorika adalah seni bertutur untuk memaparkan kebenaran. Kebohongan bukanlah sebuah retorika. Sehingga retorika menjadi sebuah komunikasi bahasa verbal/lisan dan non verbalnya adalah tulisan.

Pidato SBY sarad dengan retorika, sebagai seni berbicara, karena jika ditelaah pidatonya sebagai komunikasi verbal/bahasa lisan, yang kemudian dijadikan sebuah teks menjadi menjadi sebuah teks (non verbal). SBY tidak hanya piawai dalam strategi namun juga sangat piawai dalam permainan kata-kata yang bisa menumbuhkan cita rasa tersendiri untuk memahami dan cenderung untuk menumbuhkan rasa optimisme bagi siapa saja yang membaca atau mendengarkanya terutama bagi para pendukungpendukungnya. Namun ini juga perlu untuk dikaji lebih dalam lagi nanti dalam pembahasan melaui teori Teun A.Van Djik

Dalam Buku Retorika: Seni Berbicara karya Suhandang (2009 : 28), retorika diartikan sebagai bentuk komunikasi di mana seseorang menyampaikan buah pikirannya baik lisan maupun tulisan kepada hadirin yang relatif banyak dengan pelbagai gaya seperti bagaimana cara berbicara atau cara bertutur, dan bagaimana jika selalu dalam situasi tatap muka (face to face) baik langsung maupun tidak langsung. Sedangkan menurut Rahmat (2001:10), retorika adalah ilmu yang mempelajari bagaimana cara mengatur komposisi kata-kata agar timbul kesan yang telah dikehendaki-nya pada diri khalayak. Retorika bisa diartikan sebagai pemekaran bakat tertinggi manusia, yakni suatu rasio dan cita rasa lewat bahasa sebuah kemampuan untuk berkomunikasi dalam tataran pikiran.

Dalam hal ini SBY mempunyai bakat sebagai pimpinan untuk memberikan wawasan dan kepercayaan kepada publik bahwa ia memang berbakat dalam beretorika dan mampu berkomunikasi dalam tataran pikiran. Dia juga pandai mengatur kata-kata dan pemilihan kata dengan komposisi kata yang sempuran sehingga mudah dipahami dan dimengerti. Mengumpulkan wartawan dalam pidatonya dan direkam oleh salah satu televisi secara langsung, menunjukkan peran SBY bahwa sebetulnya apa yang akan diucapkan atau dipidatokan begitu penting dan dinantikan publik.

Sebelum lebih lanjut membahas persoalan yang ada, silakan simak (baca) hasil pidato SBY yang dituangkan dalam teks pidato :

Terima kasih Pak Prabowo.

Bismillahirrohmanirrohim.

Assalamualaikum warahmatullahi wabarakatuh.

Salam sejahtera untuk kita semua.

Alhamdulillahirobbilalamin. (kalimat pembuka) 
Saudara-saudara, saya bersyukur dan mengucapkan terima kasih kepada Bapak Prabowo, hari ini beliau berkenan menerima kunjungan balasan saya setelah beliau berkunjung ke tempat saya pada tanggal 24 Juli yang lalu. Benar, banyak hal yang kami bicarakan pada pertemuan kedua ini, namun sebelumnya tadi beliau juga berpesan kepada saya untuk ikut menyampaikan bela sungkawa atas terjadinya musibah di Nusa Tenggara Barat. Ada saudara-saudara kita yang meninggal dunia, ada yang luka-luka dan ada kerusakan harta benda. Tentu kami mendoakan agar para keluarga yang ditinggalkan oleh orang-orang yang sangat dicintainya tabah, tawakal. Dan kita berharap negara, pemerintah, utamanya pemerintah daerah bisa mengatasi, mengelola bencana alam ini

sambil melakukan perbaikan dan rehabilitasi atas kerusakan yang terjadi akibat gempa bumi ini. (paragraph 1)

Saudara-saudara, saya tidak suka beretorika, saya bukan tipe pemimpin yang mudah dan suka

berjanji. Oleh karena itulah, pembicaraan kami berdua tadi hampir 2 jam itu betulbetul dengan jernih, jujur dan terbuka. Melakukan identifikasi apa saja persoalan yang dihadapi oleh rakyat kita. Terutama saudara-saudara kita, golongan tidak mampu dan golongan miskin yang jumlahnya mencapai sekitar 100 juta orang. Kami sepakat bahwa persoalan yang dihadapi mereka itulah yang harus menjadikan prioritas bagi pemimpin dan pemerintahan yang akan datang untuk mengatasinya secepat-cepatnya. Jadi kalau mereka mengalami kesulitan, sulit mendapatkan lapangan pekerjaan, pendapatan yang dinilai pas-pasan, daya beli yang lemah akibat harga-harga sudah naik dan terus naik, maka itulah APBN kita, kebijakan fiskal kita, alokasi sumber daya kita harus diutamakan untuk mengatasi kesulitan rakyat itu.(paragraf2)

Dari mana kita tahu?

Pertama-tama kami mempelajari semua hasil survei. Survei itu, rakyat kita biasanya puas terhadap 12345, kemudian mereka sangat tidak puas terhadap ABCDE. Itulah pertama yang kami lihat, semua lembaga survei. Kemudian kami sering sekali bertemu rakyat, sering kami mendengarkan suara grassroots, ternyata sama. oleh karena itulah, visi dan misi yang akan dibangun oleh tim Pak Prabowo berorientasi kepada itu semua. Menurut saya, kalau orientasinya itu, itulah yang menjadi harapan rakyat. Tentu tidak melupakan pentingnya menghidupkan nilai-nilai kebebasan dan demokrasi. Ingat, itu amanah reformasi. Perlu menegakkan hukum secara adil, termasuk pemberantasan korupsi yang tidak tebang pilih itu juga harapan rakyat. Terus meningkatkan kemampuan pertahanan dan keamanan kita agar negara kita NKRI, kedaulatan kita bisa dilindungi. Kemudian juga hubungan internasional yang baik. Indonesia anggota G-20, kita tidak ingin menjadi penonton dan ikut saja negaranegara lain. Kita juga harus berada di situ, bagian dalam banyak hal, juga bisa mengambil tugas sebagai pemimpin atau champions. (paragraph 3)

Namun, namun dari semuanya itu, yang kita utamakan rakyat dulu, rakyat dulu, bukan yang serba benda, bukan yang material, manusianya. Itulah, kami hampir 2 jam mendiskusikan itu dan sampailah saya menyampaikan pada Prabowo, beliau setuju kalau rakyat yang dikehendaki itu, persoalannya itu, maka kepemimpinan yang akan datang dan pemerintahan yang akan datang, mestinya pemimpin yang mampu dan mau mengatasi masalah rakyat itu. Itulah akhirnya, Pak Prabowo akan mengambil keputusan nanti siapa yang akan menjadi running mate nya, yang kira-kira sesuai harapan rakyat tapi juga bisa mampu mengatasi keadaan itu. Saya sebagai pemimpin Partai Demokrat, menyerahkan penuh kepada Pak Prabowo untuk mengambil keputusan. Yang penting rakyat memberikan dukungan yang kuat, dan yang kedua diyakini pemerintahan yang akan datang bisa mengemban tugas dengan baik.(paragraph 4)

Saudara-saudara itu saja tambahan dari saya, dan saya ulangi lagi, visi dan misi kalau tidak 
salah harus diserahkan kepada KPU pada saat mendaftarkan. Saya berharap visi misi tidak usah panjang lebar, kiri kanan, terlalu muluk-muluk janjinya, nanti malah tidak bisa ditepati.Rakyat ingat terus itu. Yang simpel saja, yang konkrit saja, yang penting bisa dilaksanakan. Dengan itulah yang saya sampaikan, terima kasih atas perhatiannya, saya kembalikan waktu kepada Pak Prabowo. (paragraf 5)

pertanyaan wartawan

Kalau yang menjawab saya, ini pertemuan kedua. Pertemuan pertama terbuka lebar untuk kemungkinan Gerindra dan Demokrat berkoalisi. Setelah sekian hari kami bekerja, hari ini saya mengatakan pintu itu makin lebar dan Insya Allah, Insya Allah, dengan izin Allah Subhanahu Wa Ta'ala, kita bisa dipertemukan untuk melakukan perbaikan dan perubahan lima tahun mmendatang ke arah yang lebih baik. Kalau ditanya, Apakah masih ada diskusi Pak Prabowo presiden atau tidak, kami datang dengan satu pengertian, Pak Prabowo adalah calon presiden kita. (paragraph 6)

Transkrip Video Pidato SBY dalam pertemuan kedua dengan Prabowo pada saat SBY berkunjung ke kediaman Prabowo di Kertanegara, Jakarta, 30 Juli 2018. Video diliput dan diunggah ke media sosial Youtube dengan judul "Apa Hasil Pertemuan Prabowo - SBY?" oleh media CNN Indonesia dengan tautan sbb: https://www.youtube.com/watch?v=7GlWCSnaEZE

Teks diatas adalah pidato SBY yang disiarkan langsung oleh CNN dan diunggah di Youtube. Dalam pidatonya itu SBY mengatakan tidak berupaya untuk beretorika namun muatan isi dari pidatonya sarad dengan retorika. Retorika menjadi sebuah telaah atau studi yang simpatik mengenai oratoria atau seni berpidato. Melaui pidatonya SBY mengerahkan kemampuan dan kemahiran berbahasa waktu itu diabdikan untuk menyampaikan pikiran dan gagasannya kepada publik dan kelompok-kelompok massa tertentu guna mencapai tujuan tertentu.

Mari kita anaisis Pada paragraph kedua, yang diuraikannya sebagai berikut, meskipun SBY mengatakan, "Saudara-saudara, saya tidak suka beretorika, saya bukan tipe pemimpin yang mudah dan suka berjanji. Oleh karena itulah, pembicaraan kami berdua tadi hampir 2 jam itu betul-betul dengan jernih, jujur dan terbuka. dst"

kata 'saya tidak suka beretorika,' disini jelas sekali permainan kata yang menjadi awal dan kemampuan SBY dalam menyampaikan pikiran dan gagasannya melalui pidato kepada massa (public) untuk satu tujuan. Dan penjelasanpenjelasan dialinea berikutnya mempertegas dan memberikan wawasan ke arah mana SBY akan menggiring publik yang mendengar pidatonya ataupun yang membaca teks pidatonya untuk memahami apa yang dia ungkapkan. Hal itu sesuai dengan tujuan retorika yang diungkap oleh Tasmara (1997:156), bahwa ada lima tujuan retorika yaitu ; 1. To Inform, adalah dengan memberikan penerangan dan pengertian kepada massa, untuk memberikan penerangan yang mampu menanamkan pengertian dengan sebaikbaiknya. 2. To Convise, yaitu meyakinkan dan menginsafkan. 3. To Inspire, adalah memberikan inspirasi dengan teknik dan sistem menyampaian yang baik dan bijaksana. 4.To Intertain yaitu, menghibur, menggembirakan, menyenangkan, dan memuaskan. Dan yang ke 5. To Ectuate (to put into action), yaitu mengarahkan dan mengerahkan massa untuk bertindak menetralisir dan 
melaksanakan ide yang telah dikomunikasikan oleh orator (yang berpidato) di hadapan massa.

Kalau di cermati pada masing-masing paragraph semuanya mengandung arti dan tujuan dan fungsinya sendiri sesuai dalam retorika. Sehingga itu juga dikuatkan dari pendapat Raudhonah (2007:52), bahwa retorika itu mempunyai fungsi sebagai berikut : 1. Sebagai Mass information - adalah memberi dan menerima informasi kepada publik. 2. Sebagai Mass education - adalah memberikan edukasi/pendidikan, biasa dilakukan oleh seorang guru kepada murid atau trainer dalam mentrasfer ilmu. 3. Mass persuasion-adalah untuk memengaruhi, contohnya dalam dunia bisnis dan seni bernegosiasi 4. Mass intertainement—adalah untuk menghibur. Hal tersebut biasa dilakukan oleh radio, televisi atau orang yang memiliki profesional menghibur.

Dalam kaitannya di atas Pidato SBY mengandung unsur yang berfungsi sebagai mass information-karena dalam hal ini SBY memberikan informasi atas pertemuannya dengan Prabowo untuk mengusung Prabowo sebagai Capres 2019-2024 yang akan datang untuk berkoalisi dengan partai -partai pendukung lainnya yakni Partai Gerakan Indonesia Raya (Gerindra), Partai Demokrat, Partai Amanat Nasional (PAN) dan Partai Keadilan Sejahtera (PKS). Selain itu fungsi komunikasi di dalam pidatonya juga mengandung fungsi mass persuation-Selain informasi yang tersurat ada hal tersirat didalamnya yakni kecenderungan untuk memengaruhi dan tampak jelas sekali pernyataan pada paragraph ke tiga, empat dan lima.
Sedangkan pada paragraph pertama dan kedua tampak sebagai pembuka dan penggiringan opini publik dan paragraph ke enam menjadi paragraph tertutup sebagai penekanan keberpihakan dan informasi dalam mengusung Prabowo sebagai capres 2019-2024.

Terkait dengan fungsi ada juga klasifikasi retorika berdasar jenisnya , menurut Hendrikus (1993 : 16) retorika menurut jenisnya terbagi tiga, yaitu ; 1. Monologika-ilmu tentang seni berbicara secara monolog, dimana hanya ada seorang yang berbicara. Contohnya seperti pidato, kata sambutan, kuliah, ceramah, dan deklamasi. 2. Dialogika—ilmu mengenai seni berbicara secara dialog, di mana dua orang atau lebih berbicara atau mengambil bagian dalam suatu proses pembicaraan. Contoh dialogika seperti diskusi, Tanya jawab, perundingan, percakapan dan debat. 3. Pembinaan Teknik Bicara—menjadi syarat bagi retorika. Menjadi suatu hal yang penting dalam memahami dan menguasai tehnik berbicara yang menjadi bagian dari retorika. Hal-hal penting itu adalah perhatian yang lebih diarahkan pada pembinaan teknik bernapas, teknik mengucap, pembinaan suara, teknik membaca dan berbicara dalam bercerita. Dalam hal ini SBY merupakan perpaduan dari ketiga jenis retorika tersebut.

\section{ANALISIS WACANA KRITIS (Teun Van Djik)}

Analisis wacana kritis menurut Darma (2009: 49) adalah sebuah upaya atau proses (penguraian) untuk memberi penjelasan dari sebuah teks (realitas sosial) yang mau atau sedang dikaji oleh seseorang atau kelompok dominan yang kecenderungannya mempunyai tujuan tertentu 
untuk memperoleh apa yang diinginkan. Studi yang meneliti atau menganalisis bahasa yang digunakan oleh alam, baik secara tertulis maupun lisan disebut studi analisis wacana kritis. Dengan menganalisis suatu wacana, memudahkan kita untuk mengenal dan mengetahui ideologi apa yang tersembunyi di balik teks sebuah berita. Dalam wacana ini analisis akan mengungkap beberapa pertanyaan yakni; Bagaimana proses analisis kritis wacana dari sebuah berita (teks) dimana bahasa memegang peranan yang penting sebagai alat komunikasi antar manusia untuk dapat melakukan interaksinya. Berdasarkan hirarkinya wacana merupakan tataran bahasa terlengkap, terbesar dan tertinggi. Mengapa wacana dikatakan terlengkap? Karena di dalamnya mencakup fonologi, morfologi, sintaksis, semantik dan ditunjang oleh unsur lainnya, yaitu situasi pemakaian dalam masyarakat.

Kridalaksana (2008:259) menyatakan bahwa "Wacana merupakan satuan terlengkap dalam hierarki gramatikal tertinggi atau terbesar". Lebih lanjut dijelaskan bahwa di dalam wacana tersebut terdapat konsep, gagasan, pikiran atau ide yang utuh, sehingga dapat dipahami dan dimengerti oleh para pembaca (dalam wacana tulis) atau pendengar (dalam wacana lisan). Rangkaian kata atau gambar yang ditulis oleh penulis berisi informasi yang mengandung arti dan dbutuhkan kecermatan serta ketelitian dalam penulisan. Adapun teks yang dimaksud adalah teks yang ada di dalam tulisan (dalam hal ini pidato SBY) adalah hasil proses wacana yang terkandung nilai-nilai, idiologi dan kepentingan media. Jika kita mencoba menganalisis wacana dalam media, kita akan mengetahui motif atau ideologi yang tersembunyi di balik teks berita secara sederhana dan lebih mendalam dan inilah yang disebut sebagai analisis wacana dalam hal ini memakai analisis wacana Teun A. Van Dijk karena seringkali dipakai oleh para peneliti sosial, bahasa dan humaniora maupun komunikasi. Dikarenakan mengolaborasikan elemen- elemen wacana sehingga terbilang praktis. Model yang sering dipakai ini disebut model "kognisi sosial."

Wacana merupakan suatu rangkaian kalimat serasi yang menghubungkan kalimat satu dengan kalimat lainnya sehingga membentuk suatu kesatuan. Alex Sobur dalam bukunya Suatu pengantar Untuk Analisis Wacana, Analisis Semiotik, dan Analisis Framing, menjelaskan bahwa :"mengartikan wacana adalah rangkaian ujar atau rangkaian tindak tutur yang mengungkapkan suatu subjek yang disajikan secara teratur, sistematis, dalam satu kestuan yang koheren, yang dibentuk oleh unsur segmental maupun unsur non segmental Bahasa".(2011:18). Menurut Yoce (2009:63) wacana dalam pendekatan semacam ini dipandang sebagai medium mana kelompok yang dominan mempersuasi dan mengonsumsi kepada khalayak produksi kekuasaan dan dominan yang mereka miliki, sehingga paham ideologi yang dimaksudkan oleh Teun A Van Djick, yang mengatakan, bahwa anggota komunikasi termasuk yang didominasi menganggap hal tersebut sebagai kebenaran dan kewajaran. Telah disebutkan diatas wacana dalam klasifikasinya mempunyai fungsi yang terkandung di dalamnya, wacana juga dapat 
beranjak dari pandangan fungsional, yakni wacana dipandang sebagai bahasa dalam penggunaan. Wacana juga dipahami sebagai peristiwa komunikasi, yakni perwujudan dari individu yang sedang berkomunikasi. Definisi dan pengertian wacana dalam pandangan Darma (2009:1), bahwa wacana adalah pembahasan bahasa dan tuturan yang harus ada dalam suatu rangkaian kesatuan dalam sebuah situasi, jadi wacana tidak bisa terlepas dari konteks (situasi) yang melingkunginya.

Gambar model analisis Van Dijk

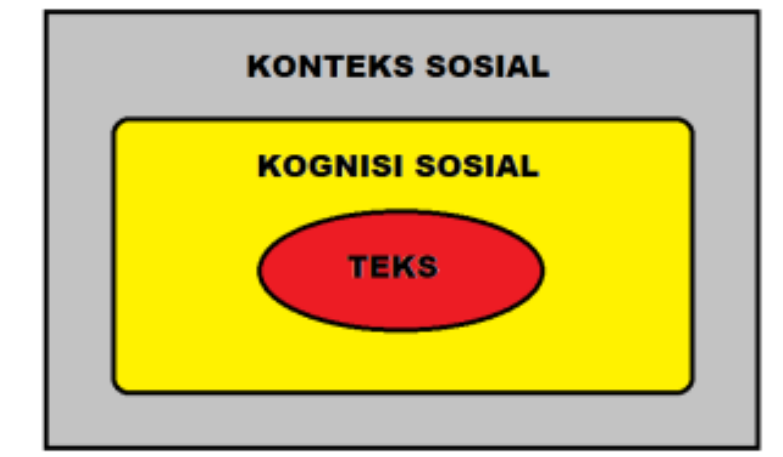

https://mufatismaqdum.wordpress.com/2011/03/25/sekilas-tentangteun-a-van-dijk-dengan- analisis-wacana-kritis/

\section{A. STRUKTUR TEKS}

Teun A. Van Djik melihat semua teks memiliki suatu aturan yang dapat dilihat sebagai sebuah piramida dalam penulisan. Kata dalam sebuah teks memberikan arti pada makna global sehingga dapat terangkai sebuah kalimat. Pemakaian kata-kata tertentu, kalimat, gaya bukan hanya dimaknai sebagai cara berkomunikasi melainkan sebagai politik berkomunikasi, suatu cara untuk mempengaruhi pendapat umum, menciptakan dukungan, memperkuat legitimasi, dan menyingkirkan lawan atau penentang. Ketika menyampaikan pesan, struktur wacana adalah cara yang efektif untuk melihat proses retorika dan persuasi yang dijalankan, contohnya akan dijelaskan satu per satu dari bagian dalam teks.

Struktur teks ini terbagi lagi dalam; a.) Stuktur Makro, b) Suprastruktur dan c) struktur mikro

a) Struktrur makro (thematic structure) -Makna global/keseluruhan dari sebuah teks dan dapat dimengerti lewat topiknya, disebut makna global. Adapun topik yang direpresentasikan ke dalam suatu atau beberapa kalimat yang merupakan gagasan utama/ide pokok wacana. Topik juga dikatakan sebagai "semantic macrostructure". Makrostruktur ini dikatakan sebagai semantik karena ketika kita berbicara tentang topik atau tema dalam sebuah teks, kita akan berhadapan dengan makna dan referensi.

\section{b) Suprastruktur (superstructure)}

Superstruktur merupakan struktur skematik (schematic structure) digunakan untuk mendeskripsikan teks, di mana keseluruhan topik atau isi global berita diselipkan. Alur harus diperhatikan dalam sebuah teks atau wacana pada umumnya sehingga menjadi satu kesatuan dalam struktur bahasa dalam artian tidak meloncat-loncar bahasanya terstruktur dengan alur yang baik mulai dari awal hingga akhir. Menurut van Dijk, arti penting dari skematik adalah strategi wartawan untuk mendukung topik tertentu yang ingin disampaikan dengan menyusun bagian-bagian dengan urutan-urutan tertentu. Jadi skematik berfungsi untuk memberikan bagian mana yang didahulukan, dan bagian mana yang akan dibuang atau disembunyikan. Penempatan bagian akhir menjadi hal yang penting dalam upaya penyembunyian agar terkesan kurang menonjol. 
c) Struktur Mikro -- Struktur wacana itu sendiri disebut sebagai struktur mikro yang terdiri atas beberapa elemen, yaitu:

\section{1) Elemen sintaksis}

salah satu elemen penting yang dimaanfaatkan untuk mengimplikasikan ideologi. Dengan kata lain, melalui struktur sintaksis tertentu, pembaca dapat menangkap maksud yang ada dibalik kalimat-kalimat dalam cerita. Melalui struktur sintaksis, penulis dapat menggambarkan aktor atau peristiwa tertentu secara negatif maupun positif. Di dalam elemen sitaksis ini terdiri dari a). Koherensi -- pertalian atau jalinan antarakata, atau kalimat dalam teks, Dua buah kalimat yang menggambarkan fakta yang berbeda dapat dihubungkan sehingga tampak koheren. b)

- Koherensi Kondisional, diantaranya ditandai dengan pemakian anak kalimat sebagai penjelas yang menjadi cermin kepentingam komunikator karena dapat memberi keterangan yang baik atau buruk terhadap sebuah pertanyaan. c). Koherensi pembeda, adalah apabila koherensi kondisional berkaitan dengan pertanyaan bagaimana dua peristiwa atau fakta dapat dibedakan dan dijelaskan.

d). Pengingkaran adalah bentuk praktik wacana yang menggambarkan bagaimana seorang wartawan menyembunyikan sesuatu yang ingin diekpresikan / disampaikan secara emplisit. Jadi wartawan itu seakan menyetujui sesuatu, padahal ia tidak setuju, caranya dengan memberikan argumentasi atau fakta yang menyangkal persetujuannya tersebut. E). Bentuk kalimat, adalah segi sintaksis yang berkaitan dengan cara berpikir logis, yaitu prinsip kausalitas yaitu menyatakan apakah A yang menjelaskan B, ataukah malah sebaliknya. Bentuk kalimat lainnya dengan pemakaian urutan kata-kata yang

memiliki dua fungsi sekaligus dengan menggunakan kalimat induktif induktif ( bentuk penulisan di mana inti kilimat ditempatkan di akhir setelah keterangan tambahan atau deduktif) dan Dedukfit (bentuk penulisan kalimat dimana inti kalimat (umum) ditempatkan di bagian awal, lalu disusul dengan keterangan tambahan (khusus). f. Kata Ganti, merupakan elemen untuk memanipulasi bahasa dengan menggambarkan suatu komunitas imajinatif. Kata ganti adalah alat yang dipakai oleh komunikator untuk menujukkan di mana posisi seseorang dalam wacana, contohnya ; saya, kami, kita, kamu, dia, mereka,

\section{2) Elemen Semantik (makna lokal)}

Elemen semantik ini sangat erat kaitannya dengan elemen leksikon dan sintaksis. Mengapa? Karena penggunaan leksikon dan struktur sintaksis tertentu dalam berita dapat menandakan makna tertentu. Contoh unsur-unsur wacana yang termasuk ke dalam elemen semantik. a) Latar, merupakan bagian berita yang dapat memengaruhi semantik (arti) yang ingin ditampilkan. Latar atau background menjadi sebuah alasan pembenar gagasan yang diajukan dalam suatu teks (Eriyanto, 2006.235). oleh karena itu, latar teks merupakan elemen yang berguna karena dapat membongkar apa maksud yang ingin disampaikan oleh wartawan. b) Detil, Elemen ini berkaitan dengan kontrol informasi yang ditampilkan seseorang (Eriyanto, 2006: 238). Detil merupakan penonjolan yang dilakukan secara sengaja 
ditampikan untuk membuat pencitraan kepada khalayak. c). Maksud, Elemen ini hampir sama dengan detil, perbedaannya adalah elemen maksud melihat informasi yang menguntungkan komunikator akan ditulis secara (eksplisit) dan jelas. Akan tetapi kebalikannya, informasi yang merugikan akan ditulis secara tersembunyi, tersamar (implisit)i. d) Pranggapan, elemen ini adalah pertanyaan atau upaya mendukung yang dipergunakan untuk mendukung makna suatu teks. Pranggapan adalah suatu usaha yang mendukung pendapat dengan memberikan premis yang bisa dipercaya kebenarannya.

\section{3) Elemen leksikon}

Elemen leksikon menyangkut pemilihan diksi atau pemilihan kata yang mempunyai makna tepat dan selaras atau dalam penggunannya yang memiliki kecocokan dalam mengungkapkan ide atau gagasan dengan pokok pembicaraan, peristiwa dan para pembaca atau pendengar pilihan kata. Beberapa fungsi dari diksi ini adalah a) agar pemilihan kata dan cara penyampaiannya dapat dilakukan dengan tepat sehingga orang lain mengerti maksud yang disampaikan. b) memperindah suatu kalimat sehingga penyampaian cerita dapat dilakukan secara runtut, baik dalam menjelaskan tokoh-tokoh ataupun mendeskripsikan latar, waktu, dan lain sebagainya. c) Membantu audiens/ pembaca mengerti apa yang disampaikan penulis atau pembicara. d) Menciptakan aktivitas komunikasi yang lebih efektif dan efisien. e) Menyampaikan gagasan atau ide dengan tepat dan f) Menjadi lambang ekspresi yang ada pada suatu ide atau gagasan.

\section{4) Elemen Retorik}

Elemen ritorik adalah hal yang menyangkut penggunaan repetisi, alitersi, metafora yang berfungsi sebagai "idiologi control." Retorik ini digunakan untuk memberi penekanan pada kalimat sehingga bermakna posifif atau negatif terhadap suatu tokoh dalam bacaan ataupun suatu peristiwa dalam berita. Elemen Retorik ini bisa dibagi dalam beberapa bagian; a) Grafis, elemem ini merupakan bagian untuk menonjolkan yang dianggap penting, biasanya dengan pemakian huruf tebal, huruf miring, garis bawah, huruf dengan ukuran lebih besar, pemakaian caption, raster, grafik, gambar, foto dan juga tabel. Pemakian angka-angka dalam berita diantaranya digunakan untuk memberikan kebenaran, pemakian jumlah, ukuran, statistik, ketelitian, dan posisi dari laporan. Van Dijk (dalam Eriyanto, 2006:258) b. Metafora, merupakan sebagian ornamen atau bumbunya berita misalnya dengan menggunakan ungkapan sehari-hari peribahasa, pepatah, petuah leluhur, kata-kata kuno, bahkan ungkapan ayat suci dipakai untuk memperkuat pesan utama.. Pemakaian metafora bisa saja dipakai sebagai landasan berfikir untuk suatu alasan pembenaran atas pendapat tertentu kepada audience.

Jika digambarkan bagan kerangka Struktur Teks analisis wacana Van Dijk dalam pidato SBY :

\begin{tabular}{|l|l|l|l|}
\hline $\begin{array}{l}\text { Struktur } \\
\text { Wacana }\end{array}$ & Hal yang diamati & Elemen & $\begin{array}{l}\text { KAJIA } \\
\text { N } \\
\text { PARAG } \\
\text { RAF }\end{array}$ \\
\hline $\begin{array}{l}\text { Struktur } \\
\text { Makro }\end{array}$ & $\begin{array}{l}\text { TEMATIK (apa makna } \\
\text { umum suatu teks yang } \\
\text { dapat dipahami dengan } \\
\text { melihat topik suatu teks, }\end{array}$ & Topik & $\begin{array}{l}\text { Pidato } \\
\text { SBY } \\
\text { Mengus }\end{array}$ \\
\hline
\end{tabular}




\begin{tabular}{|c|c|c|c|}
\hline & $\begin{array}{l}\text { dimana tema ini bukan } \\
\text { hanya berupa isi namun } \\
\text { juga dari suatu peristiwa } \\
\text { ang dikatakan?) }\end{array}$ & & $\begin{array}{l}\text { ung } \\
\text { Prabowo } \\
\text { sebagai } \\
\text { Capres } \\
2019 \text { - } \\
2024 \\
\end{array}$ \\
\hline $\begin{array}{l}\text { Suprastruk } \\
\text { tur }\end{array}$ & $\begin{array}{l}\text { SKEMATIK } \\
\text { (Bagaimana pendapat } \\
\text { disusun dan dirangkai?) } \\
\text { kerangka suatu teks, } \\
\text { bagaimana struktur dan } \\
\text { elemen wacana itu } \\
\text { disusun dalam teks } \\
\text { secara utuh }\end{array}$ & Skema & $\begin{array}{l}\text { Skema: } \\
\text { Pendahu } \\
\text { luan, } \\
\text { pembuk } \\
\text { a, isi } \\
\text { dan } \\
\text { penutup }\end{array}$ \\
\hline $\begin{array}{l}\text { Struktur } \\
\text { Mikro }\end{array}$ & $\begin{array}{l}\text { SEMANTIK ( Makna } \\
\text { yang ingin ditekankan } \\
\text { dalam teks) } \\
\text { SINTAKSIS (melihat } \\
\text { bagaimana sebuah } \\
\text { pendapat } \\
\text { disamsampaikan) } \\
\text { Leksikon (Pilihan kata } \\
\text { apa yang dipakai?) } \\
\text { RETORIK (Untuk } \\
\text { mengetahui bagaimana } \\
\text { dan dengan cara apakah } \\
\text { penekanan dalam } \\
\text { kalimat dilakukan?) }\end{array}$ & $\begin{array}{l}\text { Latar } \\
\text { (Detail, } \\
\text { Maksud, } \\
\text { pra } \\
\text { anggapa } \\
\text { n, } \\
\text { nominali } \\
\text { sasi) } \\
\text { Bentuk } \\
\text { kalimat, } \\
\text { Koheren } \\
\text { si, kata } \\
\text { ganti } \\
\text { Leksiko } \\
\text { n } \\
\text { Grafis } \\
\text { (Metafor } \\
\text { a, } \\
\text { Ekspresi } \\
\text { ) }\end{array}$ & $\begin{array}{l}\text { Latar } \\
\text { (Detail, } \\
\text { Maksud, } \\
\text { pra } \\
\text { anggapa } \\
\text { n, } \\
\text { nominali } \\
\text { sasi) } \\
\text { Dalam } \\
\text { hal ini } \\
\text { baik } \\
\text { SBY } \\
\text { dan } \\
\text { Prabowo } \\
\text { telah } \\
\text { mengad } \\
\text { akan } \\
\text { pendeka } \\
\text { tan } \\
\text { sebelum } \\
\text { adanya } \\
\text { pidato } \\
\text { tersebut }\end{array}$ \\
\hline
\end{tabular}

Sumber: Eryanto, Analisis Wacana Pengantar Analisis Teks Media (2001:228)

\section{B. KOGNISI SOSIAL}

Teori kognitif sosial adalah bahwa proses belajar akan terjadi jika seseorang mengamati seorang model yang menampilkan suatu perilaku dan mendapatkan imbalan atau hukuman karena perilaku tersebut. Melalui pengamatan ini, orang tersebut akan mengembangkan harapan-harapan tentang apa yang akan terjadi jika ia melakukan perilaku yang sama dengan sang model. Harapanharapan ini akan memengaruhi proses belajar perilaku dan jenis perilaku berikutnya yang akan muncul. Namun, proses belajar ini akan dipandu oleh sejauhmana orang tersebut mengidentifikasi dirinya dengan sang model dan seberapa besar ia dapat merasakan efikasi dan perubahan pada dirinya sendiri tentang karakter dan perilaku yang melekat dapa diri seorang model.

Atas dasar pemikiran inilah aplikasi dari teori kognitif sosial dengan adanya penelitian di media massa perlu dipertegas. Banyak sekali model yang dapat dipelajari seperti suatu model yang kita lihat, dengar, atau baca di media massa. Modelmodel ini bisa jadi merupakan orang-orang yang kita amati dalam siaran berita atau program dokumenter. Karakter-karakter yang kita lihat dalam program-program drama/sinetron/film layar lebar atau televisi atau juga karakter dalam buku novel bisa memengaruhi bagi pemirsa. Tidak hanya itu karakter dari para penyanyi atau penari yang kita dengar dan lihat melalui radio atau CD dan VCD music, ataupun model-model yang ditampilkan media akan dapat mengubah perilaku baik anak-anak maupun orang dewasa karena mereka mengamati media.

Contoh teori Kognitif Sosial, Misalnya untuk kampanye tentang demam berdarah, atau Flu Burung digunakan artis terkenal atau tokoh yang menarik yang karena mengikuti anjuran pemerintah untuk pencegahan, bisa terhindar dari penyakit tersebut. Pemakaian artis terkenal atau tokoh yang menarik akan memicu orang untuk lebih waspada terhadap kedua penyakit tersebut. Kognisi sosial menurut Teun A Van Djik mempunyai dua arti, di satu sisi ia menunjukkan bagaimana proses teks itu diproduksi oleh wartawan/media, di sisi lain ia juga 
menggambarkan bagaimana nilai-nilai (misalnya yang patriarki, rasis, atau diskriminatif lainnya) itu disebarkan dan diserap oleh kognisi wartawan, dan akhirnya digunakan untuk membuat teks berita (dalam Eriyanto, 2001: 222)

Jadi disini diartikan kognisi sosial dari sebuah teks berita yang dibuat wartawan berfungsi untuk mempengaruhi pikiran dan menggiring pembaca untuk sepemahaman dengan apa yang dipikirkan oleh wartawan. Dalam hal ini menilik dari analisis wacana pidato SBY yang ditulis kembali dalam sebuah teks mengandung nilai - nilai dan fungsi dalam komunikasi yang menyinggung kajian kritis dari Van Djick. Contoh dalam kalimat,

"Pertama-tama kami mempelajari semua hasil survei. Survei itu, rakyat kita biasanya puas terhadap 12345, kemudian mereka sangat tidak puas terhadap $A B C D E$. Itulah pertama yang kami lihat, semua lembaga survei. Kemudian kami sering sekali bertemu rakyat, sering kami mendengarkan suara grassroots, ternyata sama. oleh karena itulah, visi dan misi yang akan dibangun oleh tim Pak Prabowo berorientasi kepada itu semua. Menurut saya, kalau orientasinya itu, itulah yang menjadi harapan rakyat. Tentu tidak melupakan pentingnya menghidupkan nilainilai kebebasan dan demokrasi. Ingat, itu amanah reformasi. Perlu menegakkan hukum secara adil, termasuk pemberantasan korupsi yang tidak tebang pilih itu juga harapan rakyat (Paragraf ke 3)

Pada paragraph itu terkandung teks kalimat SBY yang memberikan gambaran bahwa koalisi Gerindra ke Demokrat berdasarkan fakta-fakta yang ada Sehingga memberikan dan menggiring fungsi positif bagi pembacanya. Karena bukan berdasakan sebab Demokrat mau berkoalisi dengan Gerindra. Dalam teks itu juga terselubung kampanye untuk memilih Prabowo sebagai calon Presiden 2019-2024. Kata 'Menurut saya, kalau orientasinya itu, itulah yang menjadi menjadi harapan rakyat' memberikan fungsi sosial bahwa jika Prabowo menjadi presiden akan mengemban dan mengedepankan rakyat dengan tidak melupakan pentingnya menghidupkan nilai-nilai kebebasan dan demokrasi.' Pada teks kamlimat di paragraph itu juga memberikan fungsi untuk menegakkan hokum secara adil termasuk pemberantasan korupsi yang tidak tebang pilih. SBY yakin menurut penilaiannya dan atas dasar survey inilah ia berkoalisi dengan Gerindra karena memiliki visi dan misi yang sama. Penjelasan mendalam di jelaskan pula dalam paragraph ke empat dari pidato SBY itu

\section{KONTEKS SOSIAL}

Konteks sosial melakukan pembahasan dengan mengamati wacana yang berkembang masyarakat terkait dengan isi pidato yang disampaikan SBY. Dalam hal ini akses dan kekuasaan besar yang dimiliki SBY dalam menyebarkan pikiran dan gagasannya ke publik berupa survey - survey yang diamatinya. Atas nama rakyat dan keinginan rakyat SBY menganggap visi dan misi Demokrat sesuai dengan partai Gerindra yang akan diusungnya untuk berkoalisi dengan memberikan dukungan penuh untuk mengusung Prabowo sebagai capres 2019 - 2024 dan semua itu dikembalikan lagi ke Prabowo. Ia juga menaruh harapan dalam pengumpulan visi dan misi ke KPU tidak terlalu muluk yang terpenting bagaimana janji-janji itu 
ditepati. Mari kita simak ucapan SBY pada paragraph 5

saya ulangi lagi, visi dan misi kalau tidak salah harus diserahkan kepada KPU pada saat mendaftarkan. Saya berharap visi misi tidak usah panjang lebar, kiri kanan, terlalu muluk-muluk janjinya, nanti malah tidak bisa ditepati. Rakyat ingat terus itu. Yang simpel saja, yang konkrit saja, yang penting bisa dilaksanakan. Dengan itulah yang saya sampaikan, terima kasih atas perhatiannya, saya kembalikan waktu kepada Pak Prabowo.

Harapan-harapan ini disampaikan SBY melalui pidato yang disampaikan pada acara tersebut. Analisis konteks sosial dilakukan melalui studi intertekstualitas, yakni mengaitkan suatu wacana dengan wacana terkait yang ada sebelum dan sesudahnya. Dalam hal ini konteks yang ada dalam teks pidato SBY terjadi karena suatu wacana yang melihat melalui survey bahwa Prabowo perlu di dukung karena sesuai dengan keinginan dan amanat rakyat. Meskipun pada kenayataannya kini aspirasi, misi dan misi 02 ini kalah dalam pertarungan melawan 01 untuk menjadi presiden RI di era 2019-2024 dan pada akhirnyapun Demokrat berpaling meninggalkan Gerindra. Disini ada pemaknaan yang mendalam dalam konteks pemilihan presiden dimana kekuasaan dan kemenangan dapat membelokkan suatu kebijakan maupun keberpihakan dalam memilih, dan itulah yang terjadi.

\section{MODEL KOMUNIKASI MASSA}

Sebagai makhluk sosial yang tidak dapat berdiri atau hidup sendiri kita memerlukan adanya komunikasi, baik itu secara lisan atau verbal maupun tertulis atau non verbal. Oleh sebab itu, maka dalam kehidupan sehari-hari, manusia membutuhkan suatu media untuk saling bertukar informasi agar dapat berkomunikasi. Komunikasi massa (mass communication), bisa juga dikatakan sebagai komunikasi media massa (mass media communication). Jadi komunikasi adalah suatu cara berkomunikasi atau penyampaian informasi yang dilakukan melalui media massa (communicating with media). Definisi lain dari komunikasi massa adalah jenis komunikasi yang diperuntukkan bagi orang banyak atau masyarakat luas dan media massa sebagai perantaranya. Kata massa adalah jamak, massive, dalam jumlah yang sangat banyak. Dalam hal ini komunikasi massa dapat juga dikaitkan dengan media.

Media Menurut Arsyad dalam bukunya media pembelajaran (2011:3) kata media berasal dari bahasa latin medius yang bermakna tengah atau perantara. Gerlach dan ely (1971) mengatakan bahwa media dapat di pah \#ami secara arti luas adalah manusia itu sendiri. Dalam arti ringkas media sendiri merupakan alat untuk menyampaikan atau mengantarkan pesan pesan bermuatan pelajaran. Perluasan konsep tentang media, dimana teknologi itu bukan hanya benda ,alat, bahan, maupun perkakas tetapi berarti juga sikap atau perbuatan yang berhubungan dengan peng aplikasian ilmu.(Achsin, 1986: 10). Media Massa Dalam Santoso (2013:18) -merupakan istilah pada tahun 1920-an untuk menyebut jenis media secara khusus di desain untuk mencapai masyarakat yang sangat luas.Kelebihannya di banding media lain yaitu dapat mengatasi hambatan rung serta waktu serta dapat 
menyebarkan pesan secara serempak dan cepat kedapa khalayak yang sangat luas dan sangat heterogen. Media massa merupakan jenis sumber informasi yang sangat di senangi oleh para petani pada tahap kesadaran minat dalam proses adopsi sebuah informasi yang berdaya guna (Fauziah ardiyani, 2009)

Fungsi dari media massa adalah (Mc.Quail. 1994:70): 1. Informasi Menyediakan informasi tentang peristiwa dan kondisi dalam masyarakat dan dunia Menunjukkan, hubungan kekuasaan, Memudahkan inovasi adaptasi dan kemajuan. 2. Korelasi Menjelaskan, menafsirkan, mengomentari makna peristiwa dan informasi, menunjang otoritas dan norma-norma yang mapan, melakukan sosialisasi, mengkoordinasikan ngbeberapa kegiatan, membentuk kesepakatan, menentukan urutan prioritas dan memberikan status relaif. 3. Kesinambungan Mengekspresikan budaya dominan dan mengakui keberadaan kebudayaan khusus (subculture) serta perkembangan budaya baru, meningkatkan dan melestarikan nilai-nilai. 4. Hiburan Menyediakan hiburan, pengalihan perhatian dan sarana relaksasi, meredakan ketegangan sosial. 5. Mobilisasi Mengkampenyakan tujuan masyarakat dalam bidang politik, pembangunan, ekonomi, pekerjaan dan agama.

Media online merupaka media yang berbasis telekomunikasi serta multimedia Prihantoro (2013 :52), yang di dalamnya terdapat portal, website, radio online, tv online, pers online, serta yang lainnya. Situs berita ataupun portal online sesuai dengan namanya merupakan media ataupun pintu gerbang sebuah informasi yang memungkinkan pengakses mendapat informasi serta aneka fitur serta fasilitas online dan berita yang termuat di dalamnya dengan menggunakan akses internet mereka. Media online adalah media yang tergolong baru karena sebelumnya kita hanya mengenal media cetak dan media elektronik saja.Dalam kehidupan sehari hari sudah hampir setiap manusia sekarang ini yang menggunakan perangkat elektronik yang berbasis internet mereka dalam menunjang kegitan serta pemuatan informasi.

Terkait dengan penelitian ini komunikasi yang terbangun adalah komunikasi massa yaitu komunikasi yang dilakukan dengan salurannya berupa media massa. Massa diartikan disini mengandung pengertian orang banyak yang keberadaannya tersebar atau terpencar di berbagai lokasi yang mendapatkan informasi pada waktu yang bersamaan. Media massa sebagai alat komunkasi memegang peranan penting untuk menyampaikan suatu pesan kepada masyarakat. Media massa menjadi sebuah channel yang bisa dipakai sebagai sarana dalam proses komunikasi massa. Misalnya dengan adanya; 1) media massa cetak (printed media) berupa surat kabar, koran, majalah, tabloid, dan lain sebagainya. 2) Jenis media massa elektronik (elektronic media) yaitu seperti radio, televisi, dan film. 3) Media online (digital media) yaitu melalui program atau channel-channel seperti blog, website, maupun aplikasi-aplikasi jejaring sosial lainnya. Metoda ini memiliki Keuntungan penyebaran informasi melalui media massa adalah keunggulannya dalam penyampaian informasi 
yang sama kepada khalayak ramai dalam waktu relatif serentak.

Buku Ilmu Komunikasi Teori Dan Praktek karangan Effendi komunikasi massa memiliki pengertian yaitu: "Komunikasi yang menggunakan media massa." (1984: 20). Lasswell menjelaskan komunikasi seperti yang dikutip oleh Mulyana dalam buku Ilmu Komunikasi Suatu Pengantar, yaitu "Komunikasi pada dasarnya merupakan suatu proses yang menjelaskan siapa, mengatakan apa, dengan saluran apa, kepada siapa? Dengan akibat dan atau hasil apa? (who? Says what? In which chanel? To whom? With what effect?)" (2007:69). Komunikasi model menurut Laswell disebut model komunikasi linear, pesan mengalir dari pengirim pesan kepada penerima pesan menurut garis lurus dan tidak ada konsep umpan balik. Tugas penerima pesan hanyalah menerima pesan saja.

Menurut Laswell dalam bukunya yang berjudul Ilmu Komunikasi Suatu Pengantar mengandung 5 unsur, yaitu: 1. Sumber (source) Nama lain dari sumber adalah sender, communicator, speaker, encoder atau originator. Merupakan pihak yang berinisiatif atau mempunyai kebutuhan untuk berkomunikasi. Sumber bisa saja berupa individu, kelompok, organisasi, perusahaan bahkan negara. 2. Pesan (message) Merupakan seperangkat simbol verbal atau nonverbal yang mewakili perasaan, nilai, gagasan atau maksud dari sumber (source), 3. Saluran (channel, media) merupakan alat atau wahana yang digunakan sumber (source) untuk menyampaikan pesannya kepada penerima. Saluran pun merujuk pada bentuk pesan dan cara penyajian pesan. 4. Penerima (receive). Nama lain dari penerima adalah destination, communicate, decoder, audience, listener, dan interpreter dimana penerima meruoakan orang yang menerima pesan. 5. Efek (effect) . Merupakan apa yang terjadi pada penerima setelah ia menerima pesan tersebut. Artinya bahwa masing-masing unsur itu memiliki peranan yang sangat penting dalam membangun sebuah proses komunikasi. Bahkan kelima unsur ini saling bergantung satu sama lain. Tanpa adanya keikutsertaan satu unsur akan memberi pengaruh pada proses jalannya komunikasi. Kelima elemen dasar dari komunikasi yang dikemukakan oleh Harold Laswell di atas ini akan bisa membantu para komunikator dalam menjalankan tugas mulianya. Berhasil tidaknya suatu komunikasi tergantung dari kelima elemen dasar tersebut. Bagaimana komunikator bisa mempengaruhi komunikannya, sehingga bisa bertindak sesuai dengan apa yang diharapkan oleh komunikator, bahkan bisa merubah sikap dan perilaku dari komunikan tersebut.

Dalam kaitan ini telah dijelaskan diatas dan dapat disimpulkan bahwa kajian Teun A Van Dijk dengan analis wacananya melihat Struktur Teks, Kognisi Sosial dan Konteks Sosial yang dapat dilihat dari bentuk, fungsi dan makna. Dimana teks pidato SBY dikaitkan dengan komunkasi massa merupakan model bentuk dalam komunikasi massa, sedangkan kognisi terjadi apabila seseorang mengamati seorang model yang menampilkan suatu perilaku dan mendapatkan imbalan atau hukuman karena perilaku tersebut dan lewat pengamatannya, orang 
tersebut akan mengembangkan harapan-harapan tentang apa yang akan terjadi jika ia dapat melakukan perilaku yang sama dengan sang model. Harapan-harapan ini akan memengaruhi proses belajar perilaku dan jenis perilaku berikutnya yang akan muncul. Kognisi sosial memberikan suatu gambaran, bahwa adanya teks pidato SBY dapat berfungsi memberikan dampak positif bagi para pendukungnya terutama hubungan mesra antara Gerindra dam Dempokrat atau malah sebaliknya. SBY dalam teks pidatonya memberikan penekanan untuk dapat berkoalisi mendukung Gerindra dan bisa mengusung Prabowo sebagai Presiden RI 2019 - 2024. Diharapkan dari pidatonya memberikan pernyatan tegas dan bisa menggiring opini masyarakat bahwa Prabowo adalah pemimpin yang tepat untuk masa depan terkait dengan persamaan visi dan misi dalam membela dan mengutamakan aspirasi rakyat. Meskipun pada akhirnya SBY (Demokrat) lengser mengundurkan diri dlaam membela Prabowo dan melipir ke kubu seberang. Kognisi sosial ini memiliki peranan sebagai fungsi dalam model komunikasi

Sedangkan untuk konteks sosial dalam hal ini teks pidato SBY itu menjadi suatu pembahasan dengan mengamati wacana yang berkembang di masyarakat terkait dengan isi pidato yang disampaikannya. Akses dan kekuasaan besar yang dimiliki SBY dalam menyebarkan pikiran dan gagasannya ke publik berupa survey - survey yang diamatinya dan dengan atas nama rakyat dan keinginan rakyat SBY menganggap visi dan misi Demokrat sesuai dengan partai Gerindra yang akan diusungnya untuk berkoalisi dengan memberikan dukungan penuh terhadap Prabowo sebagai capres 2019 - 2024. SBY juga menaruh harapan dalam pengumpulan visi dan misi ke KPU tidak terlalu muluk yang terpenting bagaimana janji-janji itu ditepati. Jika diamati dan ditelisik lebih dalam ucapan-ucapan SBY ini bukan hanya retorika belaka namun juga memberikan makna dan pesan bahwa tidak perlu memiliki visi dan misi yang muluk kalau tidak bisa dilakukan. Dengan begitu dalam kaitannya dengan model komunikasi massa, konteks sosial ini memberikan makna. Sehingga kalau di buat bagan model retorika politik SBY dalam komunikas massa adalah sebagai berikut:

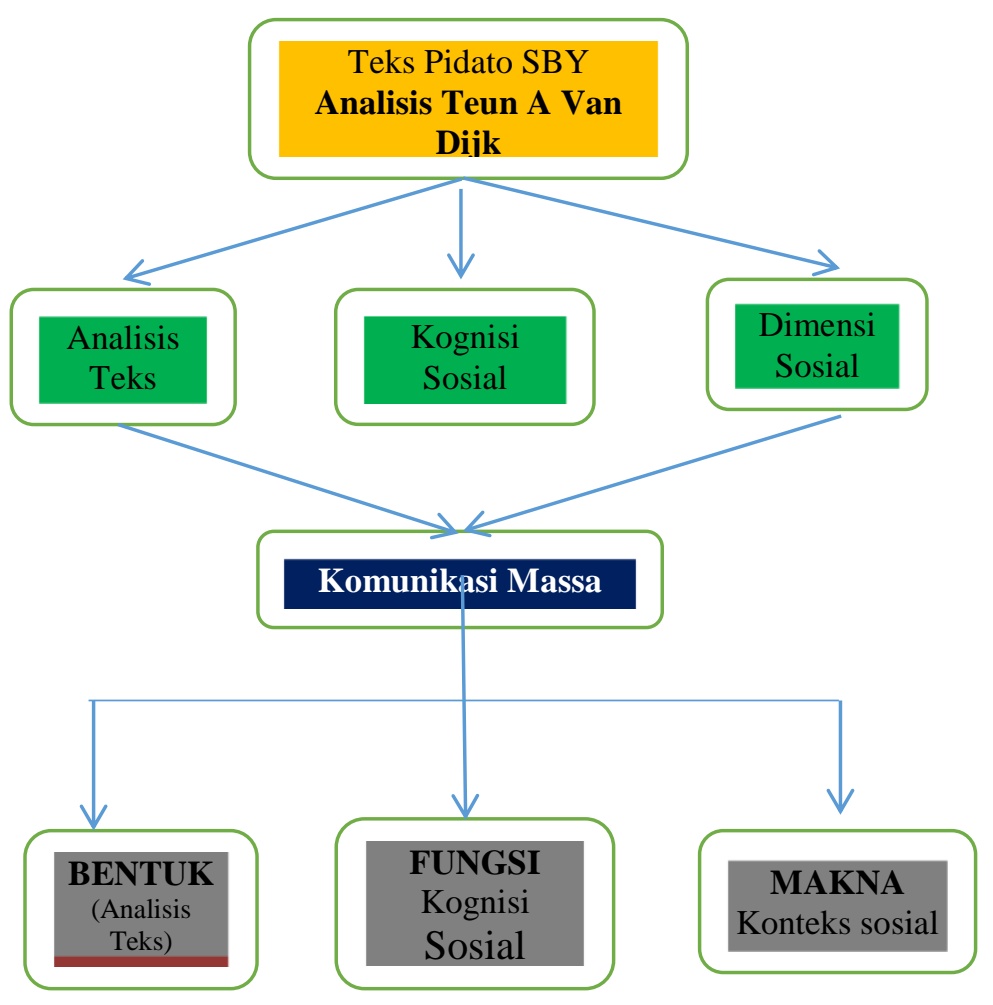

Menurut Suprapto, (2006: 13) ada empat tanda pokok / karakteristis dalam komunikasi massa adalah sebagai berikut: (1) Komunikasi massa memiliki sifat komunikan yakni sasaran komunikasi massa itu adalah yang besar dan relatif bersifat heterogen dan anonim. 
Publik/masyarakat ini tidak dapat diukur berapa jumlahnya, bagaimana latar belakang pendidikan, usia, agama, suku, jenis pekerjaan, dan lain-lain. Masyarakat yang dimaksud ini adalah semua lapisan masyarakat dengan segala perbedaannya dan melebur menjadi satu karena adanya kesamaan minat dan kepentingan yang sama. (2) Sifat Komunikasi massa adalah cepat dan serentak. Pesan secara serempak ini dilakukan secara bersamaan oleh komunikator kepada komunikan (Publik yang mendengar/membaca) yang memiliki jumlah yang besar. (3) Komunikasi massa memiliki sifat publik yang sudah jelas bahwa pesan yang ingin disampaikan tersebut ditujukan kepada masyarakat luas, bukan kepada golongan tertentu saja, sehingga isi pesan yang disampaikan harus lebih umum yang mencakup lingkungan yang umum dan universal. (4) Komunikator yang terkoordinir dimaksudkan bahwa komunikasi massa mempunyai komunikator yang telah terorganisir dengan baik dan professional, karena media massa adalah suatu lembaga organisasi, yang di dalamnya ada jurnalis, sutradara, penyiar atau pembawa acara, dan lain-lainnya.

Dalam hal ini pidato SBY dan teks pidato yang disampaikannya mengandung unsur komunikasi massa dan empat karakteristik diatas. Dimana dalam pidato tersebut bersifat untuk heterogen dan untuk orang banyak, pesan yang disampaikan juga langsung dihadapan publik, dan bukan untuk hanya satu golongan saja namun dari berbagai lapisan masyarakat. Pidato SBY juga mengundang wartawan sehingga seperti dikordinir dengan hasil yang sudah ada untuk diumumkan, pesan/pidato yang disampaikan oleh SBY di rekam dan ditayangkan oleh jurnalis baik di stasiun tv maupun media elektroniklainnya dan internet. Komunikasi Massa juga memiliki karakteristik dengan konsep klasik, diantaranya adalah ditujukan kepada masyakarat luas, yang heterogen, tersebar, serta tidak terbatas pada batas geografis dan kultural. Sehingga konsep- konsep ini juga akan dapat menjangkau masyarakat luas dengan penyampaian yang bersifat terarah, terencana dan terkonsep. Apalagi jika pesan yang disampaikan melingkupi seluruh aspek ideologi, politik sosial, ekonomi, dan budaya.

Komunikasi akan memiliki dampak yang berbeda antara satu orang dan banyak orang apabila pesan tersebut disampaikan langsung kepada banyak orang di waktu yang bersamaan. Dampak positif dari komunikasi massa mampu mengerahkan massa/masyarakat luas atau sejumlah besar orang dan perkumpulan ataupun komunitas untuk melakukan suatu hal besar yang diharapkan melalui sebuah pesan. Komunikasi massa bahkan.

Di dalam Komunikasi massa ini merupakan komunikasi yang mempunyai kekuatan sosial sehingga mampu mengarahkan masyarakat luas dan organisasi media untuk mencapai sautu tujuan yang telah dipersiapkan dan direncanakan sesuai dengan ketetapan, contohnya adalah tujuan sosial ataupun pengerahan massa seperti juga demo misalnya

Setiap komunikasi selain mempunyai maksud dan tujuan juga memberikan efek bagi massa/publik yang akan memengaruhi individu, masyarakat dan kebudayaan. Menurut Steven A. 
Chafee efek karena komunikasi bisa berdampak pada; 1. Efek terhadap individu - yang pertama efek ini dimaksudkan bahwa Komunikasi massa dapat memberikan efek ekonomis, contohnya dalam jasa lowongan pekerjaan yang disediakan oleh industri media massa. Efek kedua dapat memberikan pengaruh terhadap kebiasaan seharihari, misalnya setiap pagi orang akan memiliki kebiasaan membaca berita dahulu sebelum memulai aktifitas. Sedangkan efek ketiga adalah entertain, yaitu media massa dapat menjadi sebuah sarana 'pelarian' dari kebosanan, penat dan stress. 2. Efek terhadap masyarakat--Efek ini berkatan dengan karakter yang dimiliki oleh seseorang, masyarakat akan menilai berdasarkan pembawaan, interaksi, dan cara berfikir sesuai dengan apa yang ditunjukkan oleh media. Secara tak langsung media massa akan 'mengajak' publik untuk memberikan penilaian yang sama terhadap seseorang berdasarkan penilaian dari media massa itu sendiri. 3. Efek terhadap kebudayaanseringkali apa yang ditampilkan oleh dalam media, akan berbeda bagi setiap kebudayaan yang dianut oleh masing-masing daerah. Misalnya mengenai cara berbusana dimana sebetulnya gaya berbusana di masing-masing negara itu berbeda, namun ketika media massa menayangkannya, hal tersebut akan memberikan pengaruh dan selera fashion di daerah lain. Dalam hal ini efek yang diberikan melalui pidato SBY untuk mengusung paslon capres Prabowo sehingga memberika penambahan efek jumlah pada partai yang berkoalisi untuk mengusung Prabowo.

Media massa dan komunikasi yang bermedia massa melayani sejumlah fungsi.
Charles Wright, merinci empat empat fungsi; 1) pengawasan (surveillance). Media menyediakan arus pemberitaan yang terus menerus terkait pesan-pesan yang memungkinkan audien sadar akan perkembangan di lingkungannya yang mungkin memengaruhi mereka. Surveillance dapat terdiri dari fungsi memperingatkan, menyiagakan anggota audien terhadap bahaya semisal bada, polusi air, polusi udara, atau ancaman teroris. Komunikasi melalui media massa juga terdapat fungsi penganugerahan status (satus conjelrral function); individu, organisasi dan segala sesuatu yang diberitakan oleh media komunikasi massa, dianggap penting oleh para pembacanya. 2) Korelasi (correlation), media menunjukkan keterkaitan dan menafsirkan informasi berbagai peristiwa yang terjadi hari itu. Fungsi korelasi ini membantu para audien menentukan relevansi pesan pengawasan yang berguna untuk mereka. 3) Sosialisasi (socialization), sebagai bagian dari perluasan dari fungsi pengawasan dan fungsi korelasi, komunikasi bermedia massa mensosialisasi individu-individu agar dapat berperan serta dalam masyarakat. Media massa menyediakan pengalaman bersama, memupuk harapan tentang perilaku yang sesuai dan tidak cocok dalam masyarakat. Komunikasi bermedia massa juga memainkan peran yang sentral dalam mentrasnmisikan warisan budaya dari generasi ke generasi. 4) Hiburan (entertainment), komunikasi bermedia massa merupakan sumber hiburan massal yang meresap di tengah audien, dan memberikan pengalihan perhatian atau melepaskan audien dari taggung jawab social. 
Ruben \& Stewart dalam bukunya Komunikasi dan Perilaku (2013 : 403-404)

Dikutip dari sebuah laman reframepositive.com; makna komunikasi adalah proses bagaimana menyampaikan sebuah pesan dari seorang komunikator ke komunikan melalui sebuah saluran atau media dengan harapan mendapatkan umpan balik. Kemampuan dalam komunikasi ini adalah salah satu bentuk dari kecerdasan emosi (EQ, Emotional Quotient), para psikolog percaya bahwa EQ memiliki kontribusi yang lebih besar untuk meraih sukses dalam kehidupan kita dibandingkan dengan kecerdasan otak (IQ, Intelligent Quotient). Menurut pendapat Daniel Goleman dalam bukunya Emotional Intelligence menyatakan bahwa Intelligent Quotient (IQ) hanya menyumbangkan sekitar 20\% sementara Emotional Intelligence (EQ) memberi kontribusi sebesar $80 \%$ bagi kesuksesan kita. Jadi makna komunikasi adalah respon yang didapat, jika respon yang diterima positif maka komunikan berhasil melakukan komunikasi sesuai tujuannya, namun jika respon yang diterima negatif berarti ada kesalahan dalam penyampaian informasi.

Berbagai informasi yang bisa disampaikan berupa keinginan, ide, perasaan, fikiran atau pendapat kepada seseorang, jika gagal maka seornag komunikan harus menggunakan cara yang lain dalam mengomunikasikannya. Semakin seorang komunikan dapat memahami intensi dari setiap orang, semakin mudah ia dapat mengetahui cara yang jitu untuk mengkomunikasikan pesan atau informasi tersebut kepadanya. Ketrampilan komunikasi seperti ini difasilitasi oleh reframe positive dalam program training communication skill, dimana Anda akan dilatih untuk memperhatikan karakter komunikator, isi pesan, saluran yang bagaimana yang akan bisa merubah sikap dan perilaku komunikan, serta perubahan yang bagaimana yang diharapkan dari proses komunikasi tersebut.

Dalam mendapatkan makna komunikasi yang terjadi dalam proses komunikasi salah satunya perlu mengetahui karakterisitik dari teman bicara Anda, yaitu antara lain bagaimana dan siapa dia, latar belakangnya dari tingkat pendidikan, keluarga, suku, agama dan bahkan aliran politik dan partainya, dimana dia bekerjanya, jabatan dan posisinya, dan masih banyak lagi yang perlu diketahui dari informasi pribadi teman bicara Anda. Karakterisitik ini perlu diketahui untuk mendapatkan makna komunikasi, dan lebih mendekatkan serta memudahkan Anda sebagai awal dari pertemuan, membuka pembicaraan, dan agar Anda tidak salah dalam mengambil topik pembicaraan atau memainkan guyonan dan humor ketika proses komunikasi, sehingga respon yang Anda dapat pun dapat sesuai dengan tujuan komunikasi. Komunikasi massa mempunyai sejumlah tanggungjawab, contohnya berperilaku etis. Sangat mudah untuk dipahami mengapa perilaku etis sangat penting bagi pembicara publik. Masyarakat kaya informasi saat ini memeberikan lebih banyak kesempatan kepada perilaku penggunaan teknologi tidak etis. Sebagi contohnya adalah untuk mengirimkan sebuah pesan berpotensi berbahaya bagi ribuan orang melalui email 


\section{SIMPULAN}

Pidato adakah salah satu bentuk komunikasi, ketika pidato dituangkan dalam bahasa tulis menjadi sebuah teks yang bermakna dan disebar lewat media massa, kemudian publik dapat mengakses berita dan membacanya, maka komunikasi itu menjadi komunikasi massa. Dari retorika pidato SBY yang kemudian dituangkan dalam bahasa teks di media massa menjadi suatu kajian analisis wacana kritis yaitu studi yang meneliti atau menganalisis bahasa yang digunakan baik secara lisan (verbal) dan tulisan (non verbal). Analisis pidato Susilo Bambang Yudoyono (SBY) dengan teori analisis wacana kritis, berkoalisi dan mengusung Prabowo sebagai calon Presiden (2019-2024) dengan menggunakan teori komunikasi massa model Laswell dan teori analisis wacana kritis model Teun A Van yang dilihat dalam dimensi; (1) struktur teks, (2) kognisi sosial, dan (3) konteks sosial, penelitian ini mendapatkan suatu model komunikasi massa dari Harolld Laswell yang dapat dikembangkan dalam bentuk, fungsi dan makna. Sehingga terdapat temuan baru dalam satu model komunikasi dari penelitian ini dengan model komunikasi massa dimana struktur teks sebagai (bentuk), kognisi sosial sebagai (fungsi) dan konteks sosial sebagai (makna) yang tersirat.

\section{DAFTAR PUSTAKA}

Arikunto, S. 2013. Prosedur Peneltian: Suatu Pendekatan Praktis. Jakarta. PT. Rineka Cipta.

Baryadi, P. 2002. Dasar-dasar Analisis Wacana dalam Ilmu Bahasa. Yogyakarta. Pustaka Gondhosuli.

Darma, Y. 2009. Analisis Wacana Kritis. Bandung. Yrama Widya. Departemen Pendidikan Nasional.
Djajasudarma, T. F. 2006. Wacana : Pemahaman dan Hubungan Antarunsur. Bandung. PT Refika Aditama.

Effendy, O. U. 2005. Ilmu Komunikasi Teori dan Praktek. Bandung. Remaja Rosda Karya.

Eriyanto. 2001. Analisis Wacana: Pengantar Analisis Teks Media. Yogyakarta. LKIS. https://id.wikipedia.org/wiki/Teori_Kognitif Sosi al

Jorgensen, M. W. dan Louise J. P. 2007. Analisis Wacana Teori dan Metode. Yogyakarta. Pustaka Pelajar.

Kridalaksana, H. 2008. Kamus Linguistik. Edisi Revisi. Jakarta. PT Gramedia Pustaka Utama.

Lukman, dkk. 2006. Linguistik Indonesia. Jakarta. Yayasan Obor Indonesia.

Moleong. L. J. 2013. Meteodologi Penelitian Kualitatif. Bandung. PT. Remaja Rosadakarya.

Paina. 2010. "Tindak Tutur Komisif Bahasa Jawa: Kajian Sosiopragmatik". Disertasi. Yogyakarta. Universitas Gadjah Mada.

Pateda. 2011. Linguistik sebuah Pengantar. Bandung. Angkasa

Rani, A, dkk. 2006. Analisis Wacana: Sebuah Kajian Bahasa dalam Pemakaian. Malang. Bayu Media Publishing. https://reframepositive.com/maknakomunikasi/)

Schiffrin, D. 2007. Ancangan Kajian Wacana. Yogyakarta. Pustaka Pelajar.

Sobur, A. 2009. Analisis Teks Media, Suatu Pengantar untuk Analisis Wacana, Analisis Semiotik dan Framing”. Bandung. PT. Remaja Rosadakarya.

Suhandang, Kustadi. 2009. Retorika: Strategi Teknik dan Taktik Pidato. Bandung: Nuansa.

Sumadiria. H. 2006. Jurnalistik Indonesia, Menulis Berita dan Feature, Panduan Praktis Jurnalis Profesional. Bandung: PT. Remaja Rosdakarya.

Sumarlam, dkk. 2009. Teori dan Praktik Analisis Wacana. Surakarta. Pustaka Cakra.39

Van Dijk, A Teun. 1988. News As Discource. New Jersey: Lawrence Erlbaum Associates, Inc., Publisher. 
Van Dijk, A Teun. 1997. Discource Studies: A Multidisciplinary Introduction Volume 1. London: SAGE Publication Ltd

West, Richard dan Turner, Lynn H. 2007. Pengantar Teori Komunikasi. Jakarta: Salemba Humanika.

Yulianingsih. 2016. Pemilih Pemula dinilai Pasif. Republika. 28 Oktober 2016

Yoce, A. 2009. Analisis Wacana Kritis. Bandung. Yrama

Zaimar, O. K. S, dkk. 2009. Telaah Wacana. Jakarta. Intercultural Institut 